\title{
MOTIF DAN KEPUASAN PENGGUNAAN WEBSITE INFORMASI BERBASIS USER GENERATED CONTENT (UGC) PADA WEBSITE ZOMATO.COM
}

\author{
Abdul Lathif ${ }^{1 *}$, Mohammad Syahriar Sugandi ${ }^{1}$ \\ ${ }^{1}$ Jurusan Ilmu Komunikasi, Fakultas Komunikasi dan Bisnis, Universitas Telkom \\ *Email corresponding author: 2406doel@gmail.com \\ Diterima 16/07/2019 Direvisi 30/08/2019 Diterbitkan 31/01/2020
}

\begin{abstract}
Abstrak
Perbedaan karakter dan fitur setiap media dengan perkembangannya menimbulkan motif dan kepuasan yang beragam. Penelitian ini bertujuan untuk mengetahui gratification sought dan gratifikasi obtained serta nilai selisih dari keduanya pada pengguna website Zomato.com yang berbasis UGC di wilayah Jakarta. Penelitian ini menggunakan teori uses and gratification 2.0 sebagai kerangka kerja dan jurnal Shao (2008) sebagai motif acuan media berbasis UGC. Metode penelitian ini yakni metode survei deskriptif dengan teknik pengumpulan data survei yang dilakukan pada 100 responden di wilayah Jakarta. Pengambilan sampel penelitian ini menggunakan teknik secara non probability sampling. Pernyataan hasil survei diolah secara univariat dan statistik deskriptif. Hasil penelitian ini menunjukan motif harapan tertinggi penggunaan website Zomato.com yakni self-expression dan motif harapan terendah yakni virtual communities. Sedangkan pada motif kepuasan, persentase tertinggi yakni motif information seeking dan motif terendah yakni motif virtual communities. Nilai selisih dari gratification sought dan gratifikasi obtained didominasi oleh penurunan rata-rata tiap motifnya seperti information seeking, self-expression, mood management, entertainment, selfactualization dan virtual communities. Sedangkan motif social interaction mengalami peningkatan nilai rata-rata.
\end{abstract}

Kata Kunci: User Generated Content, Uses and Gratification 2.0, Motif, Kepuasan.

\begin{abstract}
The differences in the character and features of each media with its development give rise to diverse motives and satisfactions. This study aims to determine the gratification of sought and gratification obtained as well as the value of the difference between the two on users of UGCbased image websites in the Jakarta area. This study uses the uses and gratification 2.0 theory as a framework and journal of Shao (2008) as a reference motif for UGC-based media. This research method is descriptive survey method with survey data collection techniques conducted on 100 respondents in the Jakarta area. Sampling of this study uses non-probability sampling techniques. The survey results statement was processed univariately and descriptive statistics. The results of this study show the highest expectation motives for using websites that are self-expression and the lowest expectation motives, namely virtual communities. While the satisfaction motive, the highest percentage is information seeking motif and the lowest motive is the virtual community motif. The value of difference from sought gratification and obtained gratification is dominated by a decrease in the average of each motive such as information seeking, self-expression, mood management, entertainment, self-actualization and virtual communities. While social interaction motives experienced an increase in average value.
\end{abstract}

Key Words: User Generated Content, Uses and Gratification 2.0, Motive, Satisfaction. 


\section{PENDAHULUAN}

Perkembangan atas kebutuhan informasi semakin meningkat setiap tahunnya yang kemudian akan mengubah cara seseorang dalam mendapatkan sebuah informasi yang dibutuhkan. Dahulu informasi yang didapat hanya terbatas dari perkataan orang tua namun saat ini kapanpun, siapapun dan dimananpun bisa mendapatkan informasi sesuai apa yang mereka butuhkan dengan banyaknya pilihan media atau sumber informasi yang semakin beragam terlebih dengan adanya teknologi internet. Keberadaan media baru seperti internet bisa melampaui pola penyebaran pesan media tradisional.

Perkembangan teknologi internet yang awalnya dianggap sebagai media komunikasi satu arah kini berkembang secara teknologi dan fungsinya yang melibatkan pengguna sebagai kontributor informasi. Termasuk kegiatan memberikan ulasan atau informasi terhadap tempat makan salah satu contohnya. Kebiasaan masyarakat yang aktif mencari informasi atau ulasan menjadi salah satu dampak dalam perkembangan teknologi Kegiatan memberikan ulasan oleh pengguna disebut dengan UGC (User generated content). Konsep UGC adalah pengguna memiliki peran aktif mengakses dan menggunakan media untuk memenuhi kebutuhan mereka.

Dalam dunia kuliner, muncul tren baru pada masyarakat perkotaan untuk makan diluar rumah atau biasa disebut wisata kuliner (Nugroho \& Ferdiana, 2014). Perkembangan internet dalam pemenuhan kebutuhan informasi akan pangan, masyarakat saat ini melakukan pencarian informasi terlebih dahulu tentang tempat makan atau restoran yang akan mereka kunjungi. Salah satu fenomena yang menarik saat ini adalah fenomena "makan di luar" atau dengan bahasa lainnya yaitu "eating out". Makan di luar muncul sebagai bagian dari kehidupan sosial masyarakat urban. Gaya hidup ini banyak muncul di kota yang memiliki banyak pusat perbelanjaan dan makan yang menjadi persaingan para produsen dalam mendapat konsumen. Riset yang dilakukan oleh Nielsen mengenai gaya hidup masyarakat Indonesia menunjukan bahwa terdapat angka sebesar 11 persen masyarakat Indonesia bersantap atau jajan diluar rumah paling tidak 1 kali dalam sehari (Handayani, Indah 2017).

Kegiatan melihat ulasan pengguna dalam website dilakukan ketika mereka yang belum memiliki pengalaman pada restoran yang akan di kunjungi atau menu makanan yang akan dipesan untuk melihat berdasarkan pendapat orang yang memiliki pengalaman sebelumnya. Banyak media-media online yang memberikan fasilitas pada masyarakat dalam melihat ulasan-ulasan tentang restoran. Masyarakat aktif memberikan ulasannya dalam website atau aplikasi ketika mereka telah memiliki pengalaman pada suatau restoran, sebagai salah satu contohnya untuk membantu memberikan pertimbangan dalam penentuan keputusan. Dengan adanya peran aktif masyarakat atau pengguna dalam memberikan informasi dalam website merupakan bentuk partisipasi atas perkembangan atau karakteristik dari web 1.0 menjadi web 2.0.

Zomato adalah layanan direktori tempat makan yang dikembangkan di India dan saat ini telah dioperasikan di Indonesia. Country Manager Zomato, Karthik Shetty mengatakan bahwa aplikasi Zomato memiliki informasi mendetil dari 30.000 restoran lebih di Indonesia, lebih dari 2 juta pengguna yang unik, dengan traffic bulanan mencapai 6 juta kunjungan untuk Jakarta saja. Aplikasi ini termasuk ke dalam sistem pendukung keputusan yang membantu pengguna untuk memilih tempat makan yang disesuaikan degan kebutuhan pengguna berdasarkan informasi yang disajikan. Hal ini tampak pada aplikasi yang memberikan pertanyaan dan pilihan kepada pengguna, mengenai lokasi kota dimana pengguna berada, disana terdapat beberapa pilihan wilayah dengan kota yang terkait dengan kota pengguna, jenis tempat, kisaran harga, serta jenis makanan yang akan dimakan.

Sebuah website yang bernama similarweb.com mencatat bahwa website Zomato.com menempati urutan terbesar pertama dari website kategori food and delivery dari seluruh dunia. Website Zomato menjadi website satu-satunya yang menggunakan fitur user generated content diantara ketiga website dengan peringkat terbesar tersebut, yakni Pizzahut.com dan Dominos.com 


\section{PERFORMANCE}

Jurnal Personalia, Financial, Operasional,

Marketing dau Sistem Informasi

Performance. Volume 27 Nomor 1 Tahun 2020, 01-11

sebagai pesaingnya. Jika dibandingkan dengan website yang memiliki konsep user generated content Zomato memiliki posisi paling atas daripada website Qraved.com dan Openrice.com, Hal tersebut menjadi salah satu bukti perkembangan website berbasis user generated content memiliki peminat yang besar di era sekarang meskipun jumlah dari website dengan konsep UGC masih belum terlalu banyak serta menjadi bukti bahwa Zomato menjadi website informasi berbasis user generated content terbesar di dunia dalam bidang restorasi dan kuliner. Penelitian ini menggunakan kategori pembagian interval usia yakni dengan menggunakan tiga rentang usia berdasakan pengelompokan oleh Departemen Kesehatan Republik Indonesia yakni remaja akhir (17-25 tahun), dewasa awal (26-35 tahun), dan dewasa akhir (35-55 tahun) (depkes RI, 2009).

Salah satu keunggulan dari teknologi website Zomato adalah algoritma yang menentukan popularitas restoran yang ada di situs Zomato. Algoritma ini tidak hanya mengkalkulasi rating restoran berdasarkan hitungan rata-rata dari rating yang diberikan pengguna. Nilai rating tersebut memiliki bobot yang berbeda tergantung kredibilitas pengguna yang mana pengguna perlu membangun status mereka di Zomato sebelum rating yang ia berikan memberikan dampak yang besar dengan pengguna Zomato sebelumnya dan tempat makan yang mereka ulas. Hal ini untuk mengantisipasi situasi tertentu, seperti restoran yang baru dibuka dan memiliki rating yang tidak stabil hanya karena orang-orang menghujaninya dengan berbagai rating baik atau buruk (indotelko.com diakses pada 9 maret 2019).

Konsep UGC yang diterapkan dari penelitian ini yakni pengguna Zomato memilih website ini untuk memenuhi kebutuhannya akan referensi dibidang kuliner dan hal tersebut sejalan dengan teori uses and gratification 2.0 karena menggunakan media baru yakni media website sebagai bentuk perkembangan dari teori uses and gratification. Teori uses and gratification sebagai model teori yang memandang khalayak sebagai pemirsa yang aktif memilih dan menggunakan media. Berkembang dari sifat media dari segi interaktivitas dalam media tersebut atau dalam hal ini media website informasi yang berbasi user generated content (UGC) Zomato sebagai salah satu bukti perkembangan dari pada generasi web 2.0. Dalam penelitian ini menggunakan jabaran motif, gratifikasi yang diharapkan (gratification sougth) dari website Zomato dan gratifikasi yang didapatkan (gratification obtained) dari pengguna yang berada pada wilayah Jakarta.

Dalam penelitian Shao (2008) menyebutkan bahwa media berbasis user generated content (UGC) ini bergantung pada tiga aktifitas yaitu aktivitas konsumsi, aktivitas partisipasi, dan aktivitas produksi. Ketiga aktifitas ini didasari oleh motif yang berbeda-beda. Aktifitas konsumtif ini didasari oleh motif pencarian informasi, hiburan dan mood management. Aktifitas partisipasi didasari oleh motif interaksi sosial dan virtual communities. Sedangkan aktifitas produksi didasari oleh motif ekspresi diri dan aktualisasi diri. Indikator-indikator penelitian tersebut akan diadopsi dalam penelitian ini sebagai kerangka kerja untuk mengetahui motif yang diharapkan dan motif yang didapatkan dibalik setiap aktifitas yang dilakukan oleh pengguna website berbasis user generated content pada website Zomato.com.

Peneliti menemukan urgensi untuk melakukan penelitian mengenai motif dan kepuasan penggunaan website berbasis UGC pada website Zomato.com di Jakarta yang diharapkan mampu memberikan kemudahan dan pilihan dalam memenuhi kebutuhan informasi. Serta diharapkan bisa memberikan gambaran yang lebih komprehesif mengenai motif-motif yang dilakukan serta kepuasan pengguna mengenai aktifitasnya dalam website. Beberapa tahun belakangan ini aktifitas Zomato mampu bersaing dengan website-website terdahulu dan serupa dari seluruh dunia. Persaingan dengan website-website yang berbasis user generated content (UGC) yang semakin banyak karena perkembangan teknologi yang terus terjadi menjadi alasan peneliti dalam melakukan penelitian tentang motif dan kepuasan penggunaan website informasi berbasis user generated content pada website Zomato.com di wilayah Jakarta. 


\section{TINJAUAN PUSTAKA DAN PERUMUSAN HIPOTESIS}

\section{Uses and Gratification 2.0}

Menurut Philip Palmgreen dalam buku Kriyantono (2006) teori uses and gratification tidak berhenti hanya motif namun berkembang dengan konsep Gratification Sought (GS) dan Gratfication Obtained (GO). Gratification sougth (GS) adalah kepuasan yang dicari atau diinginkan individu ketika mengkonsumsi suatu jenis media tertentu (radio, tv, koran). Gratifcation sougth adalah motif yang mendorong seseorang mengonsumsi media. Sedangkan gratification obtained adalah kepuasan yang nyata yang diperoleh seseorang setelah mengonsumsi suatu jenis media tertentu. Gratification sougth dibentuk dari kepercayaan seseorang mengenai apa yang media dapat berikan dan evaluasi seseorang mengenai isi media. Sedangkan, gratification obtained mempertanyakan hal-hal yang khusus mengenai apa saja yang telah diperoleh setelah menggunakan media dengan menyebutkan atau rubrik tertentu secara spesifik (Kriyantono,2006).

Pada teori uses and gratifications 2.0, "use" dimaknai sebagai aktivitas dalam menggunakan jenis new media tertentu. Dalam kaitannya dengan media website berbasis UGC, aktivitas ini terdiri atas konsumsi, partisipasi, dan produksi. Sedangkan "gratification" adalah sesuatu yang dicari atau ingin dipenuhi dari penggunaan jenis media tertentu. Hal ini juga dapat dimaknai sebagai motivasi dalam melakukan suatu hal (Sepp,2010). Teori ini dicetuskan oleh Sundar dan Limperos (2013) sebagai versi penyempurnaan dari teori uses and gratifications sebelumnya yang lebih ditujukan pada kajian mengenai penggunaan media tradisional.

Pemahaman dan pandangan atas konsep UGC dalam penelitian ini dilandasi atas objek penelitian yang mengaplikasikan konsep UGC dalam sistemnya. Dengan bantuan jaringan internet web 2.0, pengguna website diposisikan sebagai kontributor, yang membuat mereka tidak hanya diposisikan sebagai konsumen dari konten-konten yang ada, namun juga berperan dalam memproduksi konten secara simultan dan terus-menerus (Arriga dan Levina, 2008). Dalam proses berjalannya aktivitas ini, peran aktif mereka ini dapat dikaitkan pula dengan implementasi teori uses and gratifications 2.0.

Dalam penelitian Sundar dan Limperos (2013) dijelaskan pada saran penelitian tersebut bahwa penelitian-penelitian selanjutnya disarankan untuk tetap memakai konsep uses and gratification yang lampau yakni dengan membaginya antara gratification sought dan gratification obtained. "In conclusion, we recommend that uses and gratification researchers adopt an affordance-based framework for identifying gratifications sought and gratification obtained from media" (Sundar dan Limperos, 2013).

\section{Website}

Menurut Laudon (2007), website adalah kumpulan halaman web terkait dengan sebuah home page-teks dan tampilan layar grafis yang biasanya menyambut pengguna dan memberikan gambaran singkat tentang organisasi yang telah membentuk sebuah web. Penelitian ini mengkaji tentang aktifitas serta kepuasan yang terdapat dalam website informasi kuliner yakni Zomato.com dimana dalam situs tersebut terdapat informasi berupa gambar dan informasi teks yang terintegrasi dengan email dan social media kita sebagai pengguna. Website tersebut sudah mengalami perkembangan secara teknologi dimana pengguna mampu memberikan ulasan atau pendapat sebagai informasi untuk pengguna website lainnya.

\section{User Generated Content}

UGC menurut Krumm, Davies, dan Narayanaswami (2008) merupakan suatu konsep yang menggambarkan kondisi ketika orang-orang secara sukarela berkontribusi dalam penciptaan dan penyajian data, informasi, maupun media yang kemudian dapat memberi manfaat bagi orang lain. 
Performance. Volume 27 Nomor 1 Tahun 2020, 01-11

Cheong (2008) menyatakan bahwa UGC membantu penggunanya mempermudah proses komunikasi dan bertukar pikiran serta mendapatkan informasi terpercaya. Ini karena informasi berbasis UGC dikatakan cenderung lebih jujur dan reliabel, karena tidak membawa kepentingan apapun seperti iklan maupun informasi yang dikeluarkan secara resmi oleh perusahaan yang mengandung promosi.

Dalam penelitian ini penggunaan website informasi Zomato yang berbasis user generated content memberikan kesempatan pada para pengguna website untuk menunjukan partisipasi dalam memberikan informasi mengenai pengalaman mereka sesuai dengan sudut pandang mereka yang harapannya mempu memberikan referensi dalam menentukan keputusan dalam berkuliner.

\section{Motif}

Dalam penelitian Shao (2008) terdapat analisis kerangka kerja untuk menjelaskan alasan kenapa seseorang menggunakan user generated media (UGM) yakni dengan tujuh motif dan tiga aktivitas, antara lain aktivitas konsumsi, berpartisipasi dan memproduksi. Aktivitas konsumsi terdiri atas motif kebutuhan informasi, motif hiburan dan motif mood management needs; aktivitas partisipasi didasari oleh motif enhancing social connection dan motif virtual communities; sementara aktivitas memproduksi konten didasari oleh motif self-expression dan motif self-actualization. Pengertian secara lebih jelasnya dai setiap motif tersebut akan dijabarkan pada paragraf berikut.

Motif information seeking. atau pencarian informasi merupakan bagian dari aktivitas konsumsi dalam penerapan konsep media berbasis UGC. Kegiatan ini didorong atas keinginan seseorang untuk meningkatkan kesadaran dan pengetahuan akan suatu hal. Kegiatan pencarian informasi pada media berbasis UGC biasa dilakukan dengan memasukkan kata kunci tertentu atau disebut sebagai searching (Shao, 2008). Motif entertainment atau hiburan dalam aktivitas konsumsi pada media berbasis UGC dikatakan sebagai pemicu yang penting, karena hiburan yang ditawarkan bersifat ringan dan mudah dicerna sehingga cocok untuk orang-orang dengan waktu luang yang singkat. Motif entertainment juga dikatakan dapat membantu seseorang mengisi waktu serta melepaskan emosi (Shao, 2008).

Dalam aktivitas konsumsi pada media berbasis UGC, pemilihan konten yang spesifik mampu mengatur perasaan seseorang atau disebut mood management. Seperti ketika seseorang sedang dilanda depresi, mereka akan cenderung memilih mengonsumsi konten yang ringan dan menghibur (Shao, 2008). Social interaction dikatakan Shao sebagai salah satu motif yang mendasari aktivitas partisipasi pada website berbasis UGC. Interaksi mencakup user-to-content yakni seperti memberikan penilaian (rate), membagikan pada pengguna lain, berkomentar, dan lain sebagainya. Interaksi user-to-user terjadi ketika sesama pengguna saling mengirim pesan melalui fitur pesan pribadi. Aktivitas partisipasi dengan motif social interaction juga dikatakan dapat mengurangi rasa kesepian, mengurangi depresi, mengurangi perasaan terisolasi, meningkatkan penerimaan diri, dan memperluas lingkaran sosial (Shao, 2008).

Motif virtual communities mendasari seseorang berpartisipasi dalam website berbasis UGC. Ini dilakukan dengan membentuk ruang diskusi dengan sesama pengguna sehingga terbentuk hubungan personal ketika mereka dapat saling berbagi ketertarikan yang sama dan menyuarakan pendapat. Mendapat feedback dari orang lain juga dapat membuat seseorang merasa terdorong untuk berpartisipasi secara berkelanjutan (Shao, 2008).

Motif self-expression merupakan salah satu motif pendorong aktivitas produksi pada media berbasis UGC. Dengan memproduksi suatu konten, seseorang dapat mempresentasikan diri mereka yang sebenarnya, sekaligus membangun citra diri dan peran sosial sebagai usaha membentuk kesan di mata orang lain sesuai yang mereka inginkan (manajemen impresi). Motif 
self-expression juga digunakan untuk menarik respon pengguna lain dan menciptakan hubungan suportif (Shao, 2008).

Self-actualization merupakan motif lain yang mendasari seseorang memproduksi suatu konten pada media berbasis UGC. Motif ini dapat didefinisikan sebagai suatu usaha untuk mendapatkan pengakuan dan kepopuleran (Shao, 2008). Dalam penelitian ini penulis menggunakan motif menurut penelitian Shao (2008) karena motif pada penelitian tersebut relevan dengan konteks dari penelitian penulis yang mengkaji tentang motif dan kepuasan pengguna dalam platform situs informasi dimana pengguna mengakses situs tersebut yang termasuk dalam perkembangan dari new media. Maka dalam penelitian ini dirumuskan:

H1: Terdapat hubungan yang signfikan antara motif dan kepuasan pengguna website Zomato di wilayah Jakarta.

\section{METODE PENELITIAN}

Penelitian ini menggunakan metode survey kuantitatif yang menggunakan pendekatan deskriptif. Dalam penelitian ini penulis menggunakan metode penelitian survey. Sugiyono (2014:7) mendefinisikan penelitian survey adalah penelitian yang dilakukan pada populasi besar maupun kecil, tetapi data yang dipelajari adalah data dari sampel yang diambil dari populasi tersebut, sehingga ditemukan kejadian-kejadian relative, distribusi, dan hubungan-hubungan antar variabel sosiologis maupun psikologis."

Penelitian ini menggunakan teknik pengambilan sampel dengan non-probability sampling serta teknik pengumpulan data purposive sampling yakni dengan memilih responden yang telah aktif memberikan ulasan pada situs Zomato. Penentuan jumlah responden yakni dengan menggunakan rumus unknown population dari Prasetya (2011) yang meneliti sejumlah 100 responden. Teknik pengumpulan data dengan menggunakan online kuesioner dari google form yang diberikan melalui direct message atau pesan pribadi media sosial pengguna situs Zomato.

Teknik analisis data dalam penelitian ini menggunakan teknik analisis univariat dan analisis deskriptif. Analisis univariat dilakukan pada tahap awal pengolahan data dengan menampilkan tabel-tabel frekuensi. Tujuan dari analisis univariat adalah menggambarkan karakteristik sampel penelitian. Setiap sampel biasanya dipilih dari populasi yang lebih luas sehingga analisis univariat juga dianggap menerangkan karakteristik populasi (Kumar, 2007). Menurut Sugiyono (2011) statistik deskriptif adalah statistik yang digunakan untuk menganalisis data dengan cara mendeskripsikan atau menggambarkan data yang telah terkumpul sebagaimana adanya tanpa bermaksud membuat kesimpulan yang berlaku untuk umum atau generalisasi.

\section{HASIL DAN PEMBAHASAN}

Berdasarkan karakter terdapat 100 responden terdapat $59 \%$ berjenis kelamin perempuan dan 41\% laki-laki. Jika dikategorikan berdasarkan pembagian usia terdapat $46 \%$ dengan interval usia 17-25 tahun, usia 26-35 tahun sebanyak 45\% dan 9\% berusia lebih dari 35 tahun. Berdasarkan wilayah terbagi atas lima wilayah dengan persentase terbesar berada pada wilayah $28 \%$ Jakarta timur, wilayah Jakarta Selatan sebanyak $27 \%$, wilayah Jakarta Pusat 18\%, wilayah Jakarta Barat $16 \%$ dan Jakarta Utara sebanyak $11 \%$. Jika dikategorikan berdasarkan latar belakang pekerjaan sebanyak 36 responden seorang pelajar/mahasiswa, pegawai negeri sebanyak 4 responden, pegawai swasta sebanyak 33 responden, 25 responden seorang wirausaha serta 2 responden berlatar belakang lain-lain.

Dalam penelitian ini terdapat 30 butir pernyataan yang terbagi atas 2 bagian yakni bagian gratifikasi yang diharapkan dan gratifikasi yang didapatkan dengan masing-masing terdapat 15 butir pernyataan. Dalam pernyataaan tersebut menggunakan skala likert dengan empat nterval (afour-point likert scale) yakni memberikan penilaian skala 1 untuk pernyataan sangat tidak setuju 
Performance. Volume 27 Nomor 1 Tahun 2020, 01-11 hingga 4 untuk sangat setuju. Hasil dari pernyataan kuesioner penelitian dari 100 responden diperoleh data nilai rata-rata seperti pada tabel 1.

Pada tabel 1 dijelaskan nilai rata-rata dari 30 pernyataan kuesioner penelitian bahwa nilai rata-rata pernyataan tertinggi dari motif yang diharapkan pengguna situs Zomato di wilayah Jakarta yakni motif self-expression dengan nilai rata-rata 3,47 dan motif harapan terendah terdapat dalam pernyataan motif virtual communities. Dalam motif yang diharapkan pengguna memberikan harapan tentang pengekspesian diri dengan nilai yang tinggi dan tidak menjadikan komunias virtual sebagai nilai harapan mereka atau memiliki nilai harapan terendah. Sedangkan, pada motif yang didapatkan yang memiliki nilai rata-rata tertinggi yakni pernyataan pada motif social interaction dengan nilai 3,82 dan pernyataan pada motif self-actualization berada pada urutan terbawah dengan nilai rata-rata 2,62. Dalam motif yang didapatkan, pengguna website berpendapat bahwa social interaction dalam website Zomato tingkat aktivitas antara penggunanya sangat tinggi dan sesuai nilai harapan pengguna, motif virtual community konsisten sebagai motif yang didapatkan dengan nilai terendah.

Tabel 1. Nilai rata-rata hasil penelitian pengguna situs Zomato di wilayah Jakarta

\begin{tabular}{|c|c|c|c|c|}
\hline \multirow{2}{*}{ Dimensi } & \multicolumn{2}{|c|}{ Gratifikasi yang diharapkan } & \multicolumn{2}{|c|}{ Gratifikasi yang didapatkan } \\
\hline & Indikator & Rata-rata & Indikator & Rata-rata \\
\hline \multirow{6}{*}{$\begin{array}{l}\text { Aktivitas } \\
\text { Konsumsi }\end{array}$} & Information Seeking & 3,21 & Information Seeking & 3.32 \\
\hline & Information Seeking & 3,43 & Information Seeking & 3,28 \\
\hline & Information Seeking & 3,28 & Information Seeking & 3,08 \\
\hline & Entertaintment & 3,16 & Entertaintment & 2,93 \\
\hline & Mood management & 3,05 & Mood management & 3,33 \\
\hline & Mood management & 3,36 & Mood management & 2,82 \\
\hline \multirow{4}{*}{$\begin{array}{l}\text { Aktivitas } \\
\text { Partisipasi }\end{array}$} & Social Interaction & 3,54 & Social Interaction & 3,23 \\
\hline & Social Interaction & 3,11 & Social Interaction & 3,82 \\
\hline & Virtual Communities & 3,04 & Virtual Communities & 2,63 \\
\hline & Virtual Communities & 3,16 & Virtual Communities & 2,64 \\
\hline \multirow{5}{*}{$\begin{array}{l}\text { Aktivitas } \\
\text { Produksi }\end{array}$} & Self-expression & 3,47 & Self-expression & 3,17 \\
\hline & Self-expression & 2,91 & Self-expression & 2,78 \\
\hline & Self-expression & 3,61 & Self-expression & 3,57 \\
\hline & Self-Actualization & 3,12 & Self-Actualization & 2,62 \\
\hline & Self-Actualization & 3,26 & Self-Actualization & 2,93 \\
\hline
\end{tabular}

Sumber: Hasil perhitungan

Dalam penelitian ini didapatkan data nilai rata-rata dari gratifikasi yang diharapkan dan data gratifikasi yang didapatkan dari ketujuh motif serta selisih dari kedua data tersebut dari pengguna situs Zomato.com. Untuk memudahkan pemahaman dapat dilihat pada tabel berikut ini: 
Performance. Volume 27 Nomor 1 Tahun 2020, 01-11

Tabel 2. Rekapitulasi gratifikasi variable motif

\begin{tabular}{cccccc}
\hline \multirow{2}{*}{ Dimensi } & Aktivitas & $\begin{array}{c}\text { Rata-rata } \\
\text { GS }\end{array}$ & $\begin{array}{c}\text { Rata-rata } \\
\text { GO }\end{array}$ & Selisih rata-rata & Keterangan \\
\hline \multirow{2}{*}{ Aktivitas } & Information seeking & 3,307 & 3,227 & $-0,080$ & GS>GO \\
\cline { 2 - 6 } Konsumsi & Entertainment & 3,160 & 2,930 & $-0,230$ & GS>GO \\
\cline { 2 - 6 } & Mood Management & 3,205 & 3,075 & $-0,130$ & GS>GO \\
\hline \multirow{2}{*}{ Aktivitas } & Social Interaction & 3,325 & 3,525 & $+0,200$ & GS<GO \\
\cline { 2 - 6 } Partisipasi & Virtual Communities & 3,100 & 2,635 & $-0,465$ & GS>GO \\
\hline Aktivitas & Self Expressions & 3,330 & 3,170 & $-0,160$ & GS>GO \\
\cline { 2 - 6 } Produksi & Self Actualizations & 3,190 & 2,775 & $-0,415$ & GS>GO \\
\hline & Jumlah & 22,617 & 21,337 & 1,280 & - \\
\hline
\end{tabular}

Sumber: Hasil perhitungan.

Gratifikasi harapan dengan nilai tertinggi oleh pengguna website Zomato di wilayah Jakarta adalah dimensi aktivitas produksi yakni motif self-expression dengan rata-rata tertinggi 3,330 dengan alas an Motif self-expression menjadi motif dengan nilai persentase harapan terbesar dari gratification sought (GO). Motif yang terdapat dalam dimensi aktivitas produksi ini diharapkan menjadi motif yang mendorong mereka untuk melakukan produksi konten pada website Zomato. Sebagai website yang mengaplikasikan konsep UGC pada sistemnya, harapan pengguna dapat dengan bebas mengekspresikan diri melalui penciptaan konten-konten yang diakomodasi penuh melalui fitur-fitur yang terdapat pada website Zomato. Kebebasan dalam memberikan ulasan kepada tempat makan ini menjadi harapan besar dalam penelitian ini. Melihat dengan konsep web 1.0 yang belum memiliki kemampuan dari segi interaktivitas penggunanya, menjadikan bukti bahwa pengguna atau user memiliki peran aktif dalam memberikan partisipasi dan sesuai dengan perkembangan web 2.0.

Gratifikasi harapan penggunaan website Zomato dengan urutan terendah adalah virtual communities yang mendapatkan rata-rata 3,100. Motif virtual communities mendapatkan persentase harapan paling rendah dari pengguna website Zomato di wilayah Jakarta. Hasil penelitian oleh pengguna website Zomato terhadap motif virtual communities yang terdapat pada dimensi aktivitas partisipasi ini sesuai dengan realita. Website Zomato sampai saat ini mengarahkan konsentrasinya untuk mengembangkan menu komunitas untuk pengguna website Zomato dalam berinteraksi secara kelompok atau komunitas. Hal ini salah satu faktor yang dimungkinkan menjadi faktor penentu menurut pengguna website Zomato di wilayah Jakarta memiliki persentase harapan yang rendah.

Gratifikasi yang didapatkan dengan nilai tertinggi oleh pengguna website Zomato di wilayah Jakarta adalah dimensi aktivitas partisipasi dan secara spesifik indikator motif social interaction mendapatkan angka rata-rata tertinggi yaitu 3,525. Dari data gratifikasi yang didapatkan, diketahui secara perhitungan persentase indikator bahwa motif information seeking menjadi persentase yang paling banyak ditemukan pada penelitian ini yakni sebanyak $15,48 \%$. Sesuai dengan karakteristik dari website Zomato itu sendiri sebagai website informasi, pengguna mengakses website Zomato dengan tujuan untuk mendapatkan informasi atau referensi seputar tempat makan dan kuliner. Dalam Pernyataan gratification obtained pada motif information seeking yakni pengguna puas menjadikan Zomato sebagai referensi utama dan sesuai kebutuhan mereka atau dalam hal ini untuk mendapatkan informasi seputar tempat makan ataupun kuliner dan pengguna merasa puas ketika mereka menggunakan kata kunci yang spesifik untuk mencari informasi yang mereka butuhkan secara efektif masih menjadi motif dominan. Kecenderungan responden dalam mengonsumsi konten-konten yang terdapat dalam website Zomato di wilayah Jakarta dalam penelitian ini masih sangat tinggi. Hal ini sebagai bukti bahwa sampel dari responden penelitian ini 
Performance. Volume 27 Nomor 1 Tahun 2020, 01-11

merupakan pengguna yang cenderung mengakses website Zomato hanya untuk mengonsumsi konten-konten yang terdapat pada fitur-fitur website Zomato.

Gratifikasi yang didapatkan penggunaan website Zomato dengan urutan terendah adalah virtual communities yang mendapatkan rata-rata 2,635. Nilai persentase terendah dari keseluruhan indikator motif pada gratifikasi yang didapatkan yakni motif virtual communities dengan nilai persentase 12,64\%. Jika disusun berdasarkan urutan persentase tertinggi ke persentase terendah dari kedua gratifikasi, motif virtual communities secara konsisten berada pada urutan persentase terendah yakni sebesar $13,71 \%$ dari nilai total rata-rata 22,617 pada gratifikasi yang diharapkan dan $12,64 \%$ dari nilai total rata-rata 21,337 pada gratifikasi yang didapatkan.

Dari hasil data gratifikasi yang didapatkan diketahui bahwa pengguna website Zomato mendapatkan dengan adanya website Zomato dimensi aktivitas konsumsi memiliki rata-rata kepuasan tertinggi sebagai konsumsi informasi atau konten. Aktivitas partisipasi berada pada posisi kedua dengan nilai rata-rata sebanyak 3,08. Pada aktivitas tersebut terdapat pernyataanpernyataan seputar kepuasan pengguna dalam berinteraksi sosial kepada pengguna lain dan komunitas virtual pada website Zomato. Rata-rata terbawah yakni dimensi aktivitas produksi, dalam penelitian ini nilai rata-rata dimensi aktivitas produksi yakni. Pada kegiatan produksi informasi atau konten secara realistis jika dilihat dari nilai tersebut terhitung masih rendah jika dibandingkan kedua aktivitas lainnya.

Nilai selisih antara gratifikasi yang diharapkan dan gratifikasi yang didapatkan mendapatkan hasil yang didominasi penurunan nilai rata-rata. Penurunan nilai rata-rata terjadi pada enam dari tujuh motif yakni motif information seeking mengalami penurunan sebanyak 0,08 ; motif mood management mengalami penurunan sebanyak 0,13 ; motif self-expression mengalami penurunan sebanyak 0,16; motif entertainment mengalami penurunan sebanyak 0,23 ; motif self-actualization mengalami penurunan sebanyak 0,415 dan motif virtual communities mengalami penurunan sebanyak 0,465 . Satu-satunya motif yang mengalami peningkatan nilai rata-rata dari gratifikasi yang diharapkan sebesar 0,2 yakni motif social interaction.

Jika disusun berdasarkan nilai selisih terendah dari keenam motif yang mengalami penurunan nilai rata-rata dari gratifikasi yang diharapkan tersebut yakni motif information seeking sebagai motif dengan nilai selisih paling rendah. Pada urutan kedua dan ketiga adalah motif mood management dan motif self-expression. Urutan selisih dari tiga motif terakhir yakni motif entertainment, motif self-actualization dan yang terakhir yakni motif virtual communities.

\section{KESIMPULAN}

Berdasarkan hasil perhitungan analisis deskriptif pada variabel motif gratifikasi yang diharapkan (gratification sought) diketahui indikator motif jika disusun berdasarkan persentase tertinggi menuju pada persentase terendah yakni, motif self-expression sebanyak $14,72 \%$, motif social interaction sebanyak $14,70 \%$, motif information seeking sebanyak $14,62 \%$, motif mood management sebanyak 14,17\%, motif self-actualization dengan persetase $14,11 \%$, motif entertainment sejumlah $13,9 \%$ dan yang terakhir motif virtual communities sebanyak $13,71 \%$.

Berdasarkan hasil perhitungan analisis deskriptif pada variabel motif gratifikasi yang didapatkan (gratification sought) atau kepuasan pengguna website diketahui berdasarkan indikator motif jika disusun berdasarkan persentase tertinggi menuju yang terendah didapatkan, kepuasan motif information seeking sebanyak $15,48 \%$, motif self-expression sebanyak $15,22 \%$, motif mood management sebanyak $14,76 \%$, kepuasan motif social interaction sebanyak $14,52 \%$, kepuasan motif entertainment sebanyak 14,06\%, kepuasan self-actualization sebanyak 13,32\%, dan yang terakhir kepuasan motif virtual communities sebanyak $12,64 \%$. Berdasarkan rekapitulasi 
Jurnal Personalia, Financial, Operasional,

Marketing dau Sistem Informasi

Performance. Volume 27 Nomor 1 Tahun 2020, 01-11

dari gratifikasi yang diharapkan dan gratifikasi yang didapatkan bahwa motif yang memiliki peningkatan nilai rata-rata yakni motif social interaction. Sedangkan enam motif lainnya mengalami penurunan nilai rata-rata dari kepuasan pengguna website.

Penelitian ini diharapkan dapat menjadi bahan masukan bagi website Zomato.com di Jakarta agar semakin mampu memberikan kemudahan dan pilihan dalam memenuhi kebutuhan informasi. Penelitian mendatang diharapkan dapat melakukan penelitian dengan menggunakan populasi dan sampel yang lebih luas lagi.

\section{DAFTAR PUSTAKA}

Arriga, M., \& Levina, N. (2008). Social Dynamics in Online Cultural Fields. Paper presented at the 29th International Conference on Information Systems (ICIS'08).Paris

Cheong, F. (2008). Using a Problem Based Learning approach teach an intelligent system course. [versi elektronik]. Journal of information technology education, 7, 47-60.

Depkes RI. (2009). Sistem Kesehatan Nasional. Jakarta: Depkes 13

Handayani, Indah (2017, Mei 24). 11 Persen Masyarakat Indonesia Rutin Makan di Luar Rumah. Berita Satu. Diakses dari https://www.beritasatu.com/gaya-hidup/432721/11-persenmasyarakat-indonesia-rutin-makan-di-luar-rumah

Indotelko. (2016, Desember 17). Siasat Zomato Menangkan Pertarungan di Foodtech. Indo Telko. Diakses dari https://www.indotelko.com/read/1481956491/siasat-zomato-pertarunganfoodtech

Krumm, J., Davies, N. and Narayaswami, C. (2008). User generated content. Pervasive Computing, $7(4), 10-11$

Kriyantono, R. (2006). Teknik praktis riset komunikasi. Jakarta: Kencana.

Kumar, Yogesh Dwivendi. (2007). Consumer Adoption and Usage of Broadband. Pennsylvania: Idea Group Inc.

Laudon. Kenneth C., dan Laudon. Jane P. (2007). Management Information System, 10th ed, Jakarta: Salemba Empat.

Nugroho R.A., \& Ferdiana, R. (2014). Teknik Pemberian Rekomendasi Menu Makanan dengan pendekatan Contextual Model dan Multi Criteria Decision Making. Prosiding Conference on Information Technology and Electrical Engineering (CITEE 2014), p.88-94

Sepp, M. (2010). Why do people produce content to user generated media? A study of bloggers' motivations. Helsinki: Hanken School of Economics

Shao, G. (2008). Understanding the appeal of user-generated media: a uses and gratification perspective. Internet Research, 19(1), 7-25, doi:10.1108/10662240910927795

Sugiyono. (2011). Metode Penelitian Kuantitatif, Kualitatif dan R\&D.Bandung: Alfabeta.CV 


\section{PERFORMANCE}

Jumal Personalia, Financial, Operasional,

Performance. Volume 27 Nomor 1 Tahun 2020, 01-11

Sugiyono. (2014). Metode Penelitian Pendidikan Pendekatan Kuantitatif, Kualitatif, dan R\&D. Bandung: Alfabeta

Sundar, S. S., \& Limperos, A. M. (2013). Uses and grats 2.0: New gratifications for new media. Journal of Broadcasting \& Electronic Media, 57(4), 504-525. Doi: 10.1080/08838151.2013.845827 